\title{
A SIMPLE ISOCRATIC RP-HPLC METHOD FOR QUALITY CONTROL OF OSELTAMIVIR CAPSULES
}

\author{
Agim Ameti, Jasmina Slavkovska, Katerina Starkoska, \\ Zorica Arsova-Sarafinovska* \\ Department for Quality Control of Medicine, \\ Institute of Public Health of the Republic of Macedonia, \\ 50 Divizija 6, 1000 Skopje, Republic of Macedonia \\ zarsova2002@yahoo.co.uk
}

\begin{abstract}
A simple isocratic reversed-phase high performance liquid chromatographic (RP-HPLC) method was developed for determination of oseltamivir active pharmaceutical ingredient (API) in bulk drug and pharmaceuticals. The separation was achieved on a Purospher STAR ${ }^{\circledR} \mathrm{RP}-18 \mathrm{e}$ column with a mobile phase consisting of methanol $-0.02 \mathrm{~mol} \mathrm{l}^{-1}$ phosphate buffer, $\mathrm{pH} 5,50: 50(\mathrm{~V} / \mathrm{V})$. Chromatographic results demonstrated the specificity of the method for determination of oseltamivir in presence of degradation products generated in studies of forced decomposition. The limit of detection (LOD) and limit of quantification (LOQ) for oseltamivir phosphate were $0.0162 \mu \mathrm{g} \mathrm{ml}^{-1}$ and $0.0491 \mu \mathrm{g} \mathrm{ml}^{-1}$, respectively. The advantages of this method include simple sample treatment, short elution time (less than 6 min) and short analysis time (less than $10 \mathrm{~min}$ ). Furthermore, using methanol instead of acetonitrile in a mobile phase composition considerably reduces the laboratory expenses, still retaining adequate sensitivity for routine analysis as well as for evaluation of authenticity of Tamiflu ${ }^{\circledR}$ products.
\end{abstract}

Key words: oseltamivir; RP-HPLC; HPLC-DAD; quality control; pharmaceuticals

\section{ЕДНОСТАВЕН ИЗОКРАТЕН РЕВЕРЗНОФАЗЕН НРЦС МЕТОД ЗА КОНТРОЛА НА КВАЛИТЕТ НА КАПСУЛИТЕ ОСЕЛТАМИВИР}

Овој труд прикажува едноставен метод за определување на активната супстанција оселтамивир во суровина за фармацевтска намена и во готов производ со примена на реверзнофазна високо ефикасна течна хроматографија (RP-HPLC) со изократен начин на елуирање. Раздвојувањето беше изведено на колона Purospher $\mathrm{STAR}^{\circledR} \mathrm{RP}-18 \mathrm{e}$ со мобилна фаза составена од метанол -0.02 mol 1-1, фосфатен пуфер, pH 5, 50:50 ( $V / V)$. Резултатите ја потврдуваат специфичноста на методот за определување на оселтамивир во присуство на разградни продукти добиени со форсирана деградација. Границата на детекција (LOD) и границата на квантификација (LOQ) за оселтамивир беа $0,0162 \mu \mathrm{g} \mathrm{ml}^{-1}$ и $0,0491 \mu \mathrm{g} \mathrm{ml}^{-1}$, соодветно. Предностите на методот се: едноставна подготовка на примерокот, кратко време на елуирање (пократко од 6 минути) и кратко време на анализа (пократко од 10 минути). Со употреба на метанол наместо ацетонитрил се намалуваат лабораториските трошоци, а истовремено се обезбедува задоволителна осетливост за изведување рутинска анализа и евалуација на потенцијално фалсификувани примероци на Tamiflu ${ }^{\circledR}$.

Клучни зборови: оселтамивир; RP-HPLC; HPLC-DAD; контрола на квалитет; фармацевтски производи. 


\section{INTRODUCTION}

The 2009 flu pandemic is a global outbreak of a new strain of H1N1 influenza virus, often referred to colloquially as "swine flu". The virus, first detected in April 2009, contains a combination of genes from swine, avian (bird), and human influenza viruses [1]. People in at-risk groups should be treated with antivirals (oseltamivir or zanamivir) as soon as possible after the first experienced flu symptoms $[2,3]$. Therapy with a neuraminidase inhibitor is especially important for patients with underlying risk factors, including pregnancy [4], and those with severe or progressive clinical illness [5].

Oseltamivir phosphate (Figure 1), manufactured under the trade name Tamiflu ${ }^{\circledR}$ (F. Hoffmann-La Roche Ltd) as an ester-type prodrug of the neuraminidase inhibitor Ro 640802, has been developed for the treatment of $A$ and $B$ strains of the influenza virus [6]. Tamiflu $^{\circledR}$ is available as capsules containing 30 $\mathrm{mg}, 45 \mathrm{mg}$, or $75 \mathrm{mg}$ oseltamivir (in the form of oseltamivir phosphate) for oral use and as a powder for oral suspension, which when constituted with water as directed contains $12 \mathrm{mg}$ $\mathrm{ml}^{-1}$ oseltamivir base [6]. It is a widely used medication, with global experience exceeding 65 million treatment courses (between the drug's approval in 1999 and June 2010) [7].

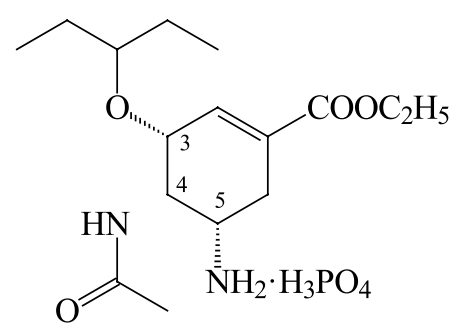

Fig. 1. Structure of oseltamivir phosphate

Oseltamivir phosphate (OP) is a white crystalline solid with the chemical name $(3 R, 4 R, 5 S)$-4-acetylamino-5-amino-3(1ethylpropoxy)-1-cyclohexene-1-carboxylic acid, ethyl ester, phosphate $(1: 1)$. The chemical formula is $\mathrm{C}_{16} \mathrm{H}_{28} \mathrm{~N}_{2} \mathrm{O}_{4}$ (free base). The molec- ular weight is 312.4 for oseltamivir free base and 410.4 for oseltamivir phosphate salt.

A literature survey for oseltamivir analysis revealed several methods based on different techniques, such as bioassay, capillary electrophoresis, cyclic voltammetry, liquid chromatographic with fluorescence, mass spectrometric and UV detection, among others [8-10]. To date, there are a few published reports of HPLC methods for measuring oseltamivir [8, 11]. A sensitive HPLC-mass spectrometry assay for oseltamivir carboxylate in plasma and urine $[12,13]$ and an HPLC assay for OP in pharmaceutical preparations [14] have been described. Joseph-Charles et al. [15] reported a HPLC method for the determination of OP in dosage forms at $226 \mathrm{~nm}$ using a Zorbax $\mathrm{CN}$ column with a mobile phase consisting of methanol and $0.04 \mathrm{M}$ formic acid $\mathrm{pH} 3.0$ (50:50). Fuke et al. [16] describe the HPLCUV detection of oseltamivir carboxylate in biological materials, following mixed mode cation exchange extraction. Furthermore, Bahrami et al. [17] presented a simple RP-HPLC method to determine oseltamivir carboxylate in human serum using a reverse phase C18 column with a mobile phase containing 0.05 M phosphate buffer - acetonitrile, $\mathrm{pH}$ 3, 70:30 $(V / V)$, and a detection wavelength of $215 \mathrm{~nm}$, while Narasimhan et al. [18] developed a stability indicating gradient elution reverse-phase HPLC method at the same detection wavelength with a Kromasil C18 column and a gradient run using a mobile phase consisted of triethylamine and acetonitrile. Most recently, Aydogmus et al. [19] developed a RP-HPLC method for determination of OP in capsules and plasma, based on the reaction of the drug with 4-chloro-7-nitrobenzofurazan in borate buffer solution, while Chabaia et al. [20] used monolithic silica HPLC column for determination of OP in pharmaceutical preparation.

Therefore, our objective was to develop a time-saving, cost-effective HPLC method with UV detection for oseltamivir determination, avoiding long steps of sample preparation and using methanol instead of acetonitrile 
in a mobile phase composition, which would reduce laboratory expenses while still retaining adequate sensitivity for routine analysis in a pharmaceutical analytical laboratory, in chemical stability studies, as well as for the evaluation of potentially counterfeit Tamiflu ${ }^{\circledR}$ products.

\section{EXPERIMENTAL}

\subsection{Chemicals and reagents}

Commercially available samples, Tami$\mathrm{flu}^{\circledR}$ capsules for oral use containing $30 \mathrm{mg}, 45$ $\mathrm{mg}$, or $75 \mathrm{mg}$ oseltamivir, in the form of oseltamivir phosphate, were used in this study. In addition to the active ingredient, each capsule contains pregelatinized starch, talc, povidone $\mathrm{K} 30$, croscarmellose sodium, and sodium stearyl fumarate. All dosages contain gelatin and titanium dioxide within their capsule shells. In addition, the $30 \mathrm{mg}$ variety contains yellow and red iron oxides; the $45 \mathrm{mg}$ variety contains black iron oxide; and the $75 \mathrm{mg}$ variety contains yellow, black and red iron oxides. Each capsule is printed with blue ink, which includes FD\&C Blue No. 2 as the colorant [6]. Oseltamivir phosphate standard was supplied by Roche Diagnostics GmbH, Mannheim. Methanol, sodium hydroxide, and hydrochloric acid were purchased from Merck (Darmstadt, Germany), while triethylamine and hydrogen peroxide were purchased from Alkaloid Ltd., Skopje. Double-distilled water was used to prepare the mobile phase solutions.

\subsection{HPLC instrumentation and conditions}

HPLC analyses were performed using an Agilent Technologies chromatographic system (Hewlett Packard, Avondale, USA) consisting of a Model 1200 Series SL pump with a Model Agilent series G-1315C DAD detector and a Model Agilent 1200 series G-1329B ALS auto sampler. Data analyses were done using Agilent Technologies HPLC 1100 software. The chromatographic separation was achieved on a reversed-phase column Purospher STAR ${ }^{\circledR}$ RP $-18 \mathrm{e}(150 \times 4.6 \mathrm{~mm}$ i.d., particle size $5 \mu \mathrm{m})$, with a guard column LiChrospher $^{\circledR} 100 \mathrm{RP}-$ $18(4 \times 4 \mathrm{~mm}$ i.d., particle size $5 \mu \mathrm{m})$ at $25^{\circ} \mathrm{C}$. The mobile phase consisted of a mixture of: methanol - $0.02 \mathrm{~mol} \mathrm{l}^{-1}$ phosphate buffer (containing $0.02 \mathrm{~mol} \mathrm{l}^{-1}$ triethylamine), $\mathrm{pH} \mathrm{5,} \mathrm{50:50}$ $(V / V)$, filtered through $0.45 \mu \mathrm{m}$ nylon filter. The

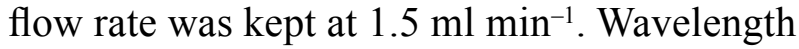
was selected by scanning a standard solution of OP over 200-400 nm using Model Lambda 12 (Perkin Elmer) UV-visible spectrophotometer. The wavelength of $215 \mathrm{~nm}$ was chosen for detection of oseltamivir phosphate. The injection volume was $20 \mu \mathrm{l}$.

\subsection{Preparation of solutions}

A stock solution of OP was prepared by dissolving $25 \mathrm{mg}$ of the OP standard in a solvent mixture (water : methanol, 50:50 $(V / V)$ ), and diluting with the same solvent up to $25 \mathrm{ml}$. Working standard solution $\left(0.3 \mathrm{mg} \mathrm{ml}^{-1}\right)$ was prepared by appropriate dilution of the stock standard solution with the same solvent. For evaluation of linearity, ten aliquots of the stock solution were suitably diluted with the same solvent to get standard solutions of OP in concentration range of $0.075-0.75 \mathrm{mg} \mathrm{ml}^{-1}$.

Twenty capsules were weighed and the net content of each capsule was calculated. Capsule powder equivalent to $30 \mathrm{mg}$ OP was accurately weighed and transferred to a 100 $\mathrm{ml}$ volumetric flask with addition of about 70 $\mathrm{ml}$ solvent mixture (water : methanol, 50:50 $(V / V))$. The mixture was sonicated in an ultrasonic bath for 15 min and volume was made up to the mark with the same solvent. All solvents and solutions for HPLC analysis were filtered through a membrane filter $(0.45 \mu \mathrm{m}$ pore size $)$ and vacuum degassed before use. 


\subsection{Method validation}

The proposed method was validated according to the guidelines set by the International Conference on Harmonization for validation of analytical procedures [21, 22]. The parameters used to validate the method of analysis were: system suitability, specificity, linearity, range, accuracy, and precision, limit of detection (LOD), limit of quantification (LOQ), specificity and robustness.

\subsubsection{System suitability}

System suitability testing is an integral part of liquid chromatographic method validation performed to check and ensure on-going performance of a chromatographic system. The system repeatability was estimated by 6 repeated injections of working standard solution at $100 \%$ of test concentration $\left(0.3 \mathrm{mg} \mathrm{m}^{-1}\right.$ $\mathrm{OP})$. The system suitability parameters were calculated according to the recommendation of the United States Pharmacopoeia [23, 24]. The limits for system suitability parameters suggested in the FDA guideline on "Validation of Chromatographic Methods" [25] were used as acceptance criteria.

\subsubsection{Specificity}

Specificity is the ability to assess unequivocally the analyte in the presence of components which may be expected to be present (impurities, degradants, matrix, etc.) [21, 22, 26]. Specificity of the proposed method was demonstrated by spiking the capsule formulation with a known quantity of OP standard, then checking for interference with the placebo. Additionally, specificity was demonstrated by the determination of OP in the presence of degradation products generated by forced decomposition. The stress conditions applied in the study were: base hydrolysis $\left(0.05 \mathrm{~mol} \mathrm{l}^{-1}\right.$ $\mathrm{NaOH}$, at room temperature, for 5 hours), acid hydrolysis $\left(1 \mathrm{~mol} 1^{-1} \mathrm{HCl}\right.$, at $90^{\circ} \mathrm{C}$, for $30 \mathrm{~min}$ utes) and oxidative degradation $\left(30 \% \mathrm{H}_{2} \mathrm{O}_{2}\right.$, at $90{ }^{\circ} \mathrm{C}$, for 10 minutes). An accurately weighed $25.0 \mathrm{mg}$ of OP standard was dissolved in 500 $\mu l$ of the respective base, acid or hydrogen peroxide and kept for specified period of time after which the volume was made up to 25.0 $\mathrm{ml}$ with the solvent mixture (water : methanol, 50:50 $(V / V))$. Blank solutions were treated in the same way.

A thermal degradation was carried out by treating OP drug substance in hot-air oven at $120^{\circ} \mathrm{C}$, for 1 hour.

\subsubsection{Linearity and range}

For evaluation of linearity the calibration curve was obtained at 10 concentration levels of OP standard solutions $(0.075-0.75 \mathrm{mg}$ $\left.\mathrm{ml}^{-1}\right)$. Additionally, to improve the specificity, we evaluated linearity of OP in the presence of excipients. We spiked placebo samples with one stock active solution at six concentration levels $\left(0.15-0.525 \mathrm{mg} \mathrm{ml}^{-1}\right)$. The solutions (20 $\mu 1)$ were injected in triplicate into a chromatographic system with the previously given chromatographic conditions. For evaluation of linearity, the peak area and concentrations were subjected to a least square regression analysis to calculate calibration equation and determination coefficient.

\subsubsection{Precision}

The precision of the analytical procedure (intra-assay precision) was investigated by analyzing six sample solutions obtained by multiple sampling of the same homogeneous sample under the prescribed conditions (at $100 \%$ of the test concentration of $\left.\mathrm{OP}\left(0.3 \mathrm{mg} \mathrm{ml}^{-1} \mathrm{OP}\right)\right)$ on the same day, by the same analyst and using the same equipment. The intermediate precision of the analytical procedure was investigated by analyzing sample solutions on three consecutive days. The precision of the analytical procedure 
was expressed as the relative standard deviation of a series of measurements.

\subsubsection{Limit of detection and limit of quantification}

Limit of detection (LOD) and limit of quantification (LOQ) of the proposed method were determined by consecutively injecting low concentrations of the standard solutions $(0.125-1.25$ $\mu \mathrm{g} \mathrm{ml}^{-1}$ ) using the proposed RP-HPLC method. LOD and LOQ were calculated in accordance with ICH guidelines [21, 22] as follows: LOD $=3.3 \mathrm{SD} / S$ and $\mathrm{LOQ}=10 \mathrm{SD} / S$, where $\mathrm{SD}$ is the standard deviation of the response ( $y$ intercept) and $S$ is the slope of the calibration curve obtained.

\subsubsection{Accuracy}

To study the accuracy of the proposed analytical method, recovery tests were conducted using the standard addition method. To discover whether excipients interfered with the analyte, known amounts of standard were added to capsule formulation samples and the resulting mixtures were analyzed by the proposed methods. The percent of recovery was calculated as follows:

$$
\text { Recovery }(\%)=\frac{C_{v}-C_{u}}{C_{a}} \times 100,
$$

where $C_{v}$ is the total amount of OP measured after standard addition, $C_{u}$ the amount of OP in the drug formulation, and $C_{a}$ the amount of OP added to the formulation.

\subsubsection{Method robustness}

The capacity of the proposed method to remain unaffected by small (deliberate) variations in parameters was evaluated in order to determine method robustness. Changes were made to the following method parameters: flow rate $( \pm$ $\left.0,1 \mathrm{ml} \mathrm{min}{ }^{-1}\right)$, organic solvent concentration $( \pm 2$ $\%$ ), wavelength of detection ( $\pm 5 \mathrm{~nm})$, buffer $\mathrm{pH}$ $( \pm 0.2 \mathrm{pH}$ units $)$, and temperature $\left( \pm 3{ }^{\circ} \mathrm{C}\right)$.

\section{RESULTS AND DISCUSSION}

\subsection{Method development}

A variety of mobile phases were investigated in the development of a HPLC method for analysis of OP. These included: methanol - water, 50:50 $(\mathrm{V} / \mathrm{V})$, acetonitrile - water, 30:70 $(\mathrm{V} / \mathrm{V})$, methanol - phosphate buffer ( $\mathrm{pH} 3.5-6.5), 50: 50$ $(V / V)$, and acetonitrile - phosphate buffer $(\mathrm{pH}$ 3.5-6.5), 30:70 (V/V). The suitability of the mobile phase was decided on a basis of the sensitivity of the assay, suitability for stability studies, ease of preparation, and use of readily available cost-effective solvents. Thus, the mobile phase consisting of methanol $-0.02 \mathrm{~mol} \mathrm{l}^{-1}$, phosphate buffer (containing $0.02 \mathrm{~mol} \mathrm{l}^{-1}$ triethylamine), $\mathrm{pH}$ 5, 50:50 $(V / V)$, was found optimal for isocratic determination of oseltamivir in pharmaceuticals. The wavelength was selected by scanning the standard solution of OP over 200-400 $\mathrm{nm}$ and the wavelength of $215 \mathrm{~nm}$ was chosen for detection of oseltamivir phosphate.

Oseltamivir was identified on the basis of retention time through comparison with the oseltamivir standard. Furthermore, the oseltamivir was identified by adding standard to sample prior to analysis, which resulted in an increased sample peak area that was proportional to the added amount. The average retention time of the oseltamivir was approximately $5.4 \mathrm{~min}$ at a flow rate of $1.50 \mathrm{ml} \mathrm{min}^{-1}$. The oseltamivir was determined in a short time as a sharp single peak. The retention time of OP we achieved in our study was shorter than those reported previously (5.4 min versus $6.4 \mathrm{~min}$ [14], $9.1 \mathrm{~min}$ [17], $10.6 \mathrm{~min}$ [18], and $18.8 \mathrm{~min}$ [16]). About $10 \mathrm{~min}$ was required for each analysis. No interference from other degradation products was observed (Figure 2). 


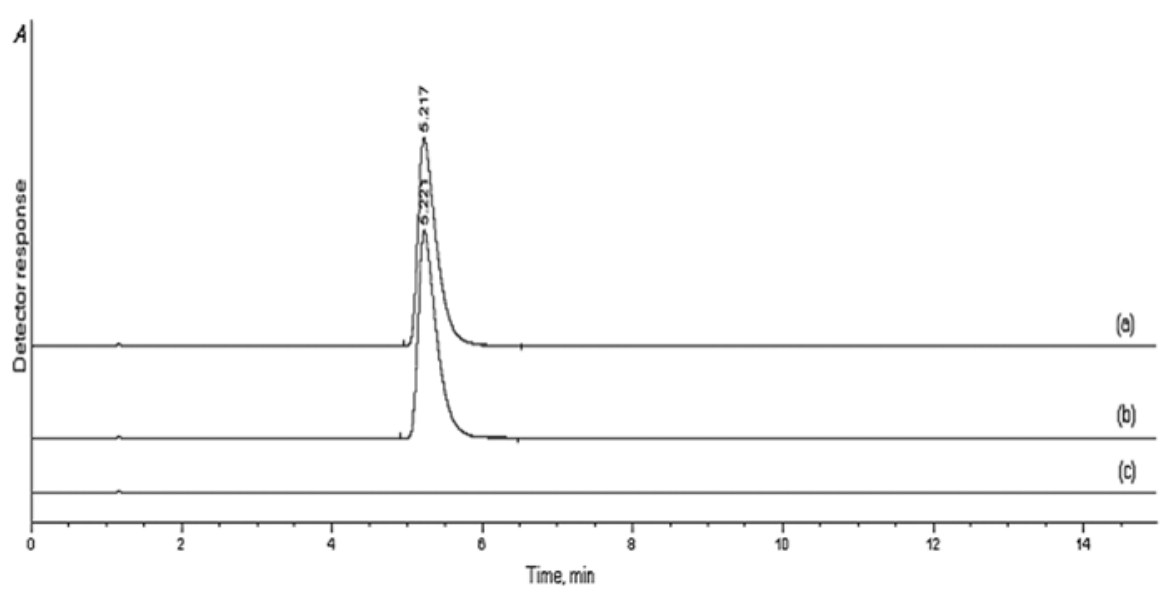

Fig. 2. Typical chromatograms obtained from oseltamivir in standard solution (a), sample solution (Tamiflu ${ }^{\circledR}$ capsules) (b), mobile phase (c)

\subsection{Method validation}

\subsubsection{System suitability}

The results of system suitability test were found within the acceptable range [25] indicating that the system was suitable for the intended analysis (Table 1).

Table 1

\section{Results of system suitability test}

\begin{tabular}{lrc}
\hline \hline \multicolumn{1}{c}{ Parameter } & Results & Parameter limit \\
\hline RSD of retention time & $0.11 \%$ & $<1 \%$ \\
RSD of peak area & $0.18 \%$ & $<1 \%$ \\
Capacity factor $k^{\prime}$ & 3.42 & $>2$ \\
Tailing factor $T$ & 1.3 & $<2$ \\
Theoretical plate & 3444 & $>2000$ \\
\hline \hline
\end{tabular}

$\mathrm{T}$ a b 1 e 2

\subsubsection{Specificity}

In the specificity study, standard solutions of OP and the sample solution were injected and a single peak was obtained for OP, which indicates that there was no interference from the excipients used or from the mobile phase. Furthermore, forced degradation study was undertaken in order to demonstrate the specificity of proposed method. This study also provides information about the degradation pathways and degradation products that could form during storage: OP undergoes degradation in acidic and alkaline hydrolytic conditions whereas it is relatively stable when exposed to dry heat and oxidation. The result of forced degradation studies, with approximate \% degradation and relative retention time (RRT) of degradation products is given in Table 2 .

The drug was rapidly degraded under acidic condition using $1 \mathrm{~mol} \mathrm{l}^{-1} \mathrm{HCl}$, at $90{ }^{\circ} \mathrm{C}$, for 30

\section{Results of forced degradation study of oseltamivir}

\begin{tabular}{lcr}
\hline \hline Stress degradation condition & $\begin{array}{c}\text { Approximate degradation } \\
\text { observed (\%) }\end{array}$ & $\begin{array}{c}\text { Relative retention time } \\
\text { of degradation products }\end{array}$ \\
\hline Acid hydrolysis & 54.59 & $0.35,1.27$ \\
Base hydrolysis & 5.18 & $0.32,0.63$ \\
Thermal degradation & 3.04 & $0.32,0.62,0.91,1.32$ \\
Oxidative degradation & 4.08 & $0.32,0.62,0.89$ \\
\hline \hline
\end{tabular}


minutes. The degradation was associated with a rise in a major degradation product at RRT 1.27 and a minor degradation product at RRT 0.35 (Figure 3-a).

The extent of hydrolysis under alkaline conditions was lower as compared to that in acidic conditions, forming minor degradation products at RRT 0.32 and 0.63 (Figure 3-b).
The drug was considerably stable to $30 \%$ hydrogen peroxide at $90{ }^{\circ} \mathrm{C}$ for 10 minutes: only minor degradation products at RRT 0.32, 0.62, 0.91 and 1.32 were formed (Figure 3-c).

No major degradation product was observed after the exposure of the drug substance to a temperature of $120^{\circ} \mathrm{C}$ in a hot-air oven for $1 \mathrm{~h}$; minor degradation products at RRT $0.32,0.62$, and 0.89 were formed (Figure 3-d).
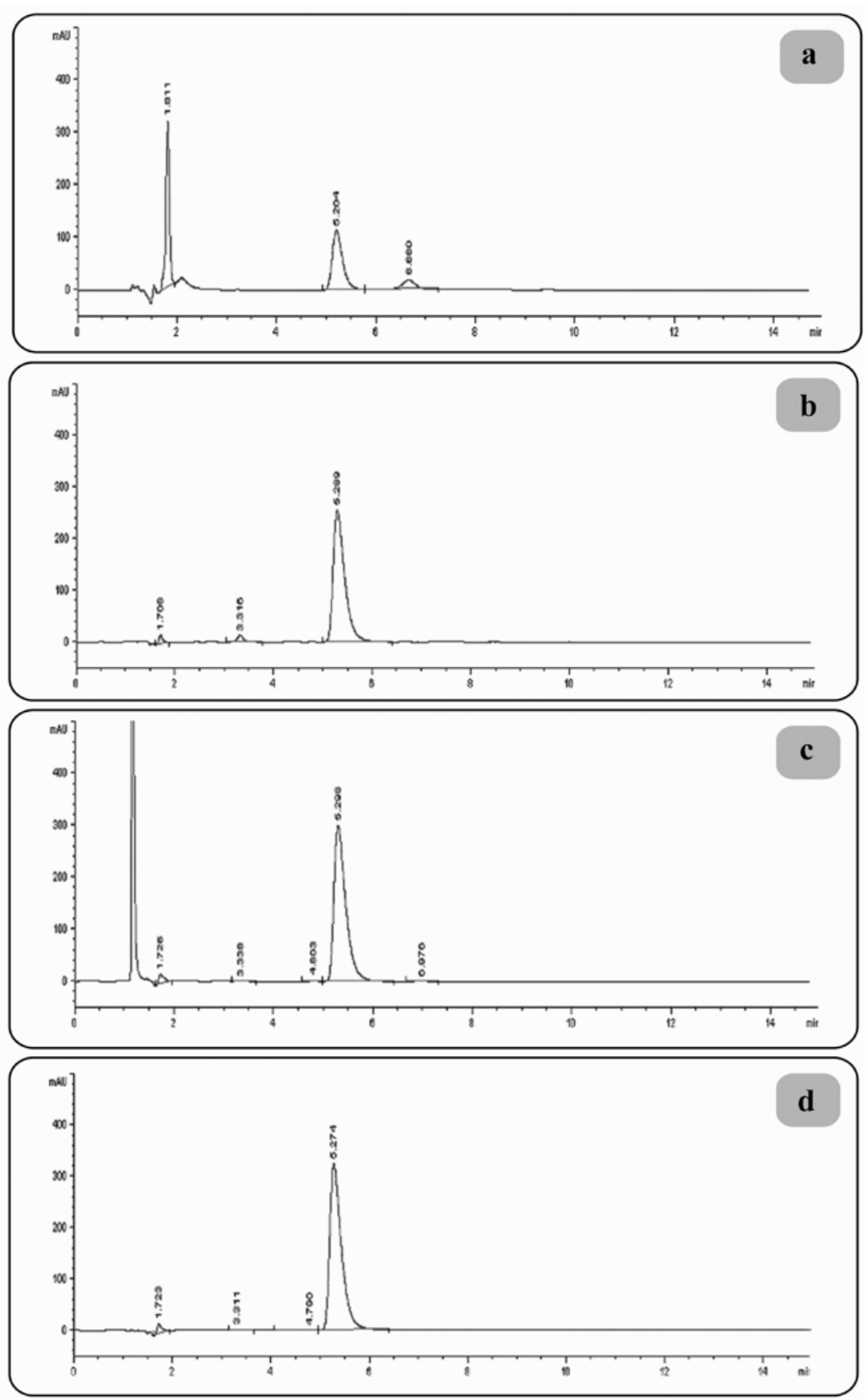

Fig. 3. Chromatograms of acid degradation (a), basic degradation (b), oxidative degradation (c), and thermal degradation of oseltamivir (d) 
HPLC chromatograms of hydrolytic, oxidative and thermal degradation of OP show that OP peak is well separated from all the degradation products formed during the different stress conditions. Thus specificity study ensures that the developed analytical method is able to separate and quantify OP in presence of different degradation products.

\subsubsection{Linearity and range}

In the present study, linearity was studied in the concentration range $0.075-0.75 \mathrm{mg} \mathrm{ml}^{-1} \mathrm{OP}$ and the following regression equation was found by plotting the peak area $(y)$ expressed in mAU versus the OP concentration $(x)$ expressed in $\mathrm{mg}$ $\mathrm{ml}^{-1}: y=18525 x-27.193\left(r^{2}=0.9999\right)$. The determination coefficient $\left(r^{2}\right)$ demonstrates the excellent relationship between the peak area and concentration of OP. The calibration curves of oseltamivir API and oseltamivir with placebo were linear. The regression lines were not significantly different from a curve passing through the origin $y$ $=\mathrm{a} x .(P$-value of the slope $>0.05)$. The excipients had no influence and there was no matrix effect observed (Table 3).

\subsubsection{Precision and accuracy}

The variation in results obtained within a day $(\mathrm{RSD}=0.50 \%, \mathrm{RSD}=0.79 \%$ and $\mathrm{RSD}=$ $0.90 \%$, for Tamiflu ${ }^{\circledR} 30 \mathrm{mg}$ capsule, $45 \mathrm{mg}$ capsule, and $75 \mathrm{mg}$ capsule, respectively) and day to day variations $(\mathrm{RSD}=0.15 \%)$ for OP determination was very low $(\leq 2 \%)$, which confirmed the precision of the method. The statistical data is shown in Table 4.

$\mathrm{T}$ a b 1 e 3

Characteristics of the linear regression analysis

\begin{tabular}{lcc}
\hline \hline Parameter & Oseltamivir API $^{a}$ & Oseltamivir + excipients \\
\hline Linearity range $\left(\mu \mathrm{g} \mathrm{m}^{-1}\right)$ & $0.075-0.75$ & $0.15-0.525$ \\
Slope & 18525 & 18728 \\
Intercept & -27.193 & 22.911 \\
Determination coefficient $\left(r^{2}\right)$ & 0.9999 & 0.9999 \\
$\mathrm{SE}^{b}$ of the intercept & 32.542 & 25.331 \\
$\mathrm{SE}_{\text {of the slope }}$ & 69.928 & 70.171 \\
$P$-value of the slope & 0.428 & 0.417 \\
\hline \hline
\end{tabular}

${ }^{a}$ Mean value of 3 determination

${ }^{b} \mathrm{SE}$ - Standard error

Table 4

Precision of the method

\begin{tabular}{llccc}
\hline \hline Precision & Parameter & \% of declared content $(X)$ & RSD (\%) & Bias (\%) \\
\hline \multirow{3}{*}{ Intra-assay precision $^{a}$} & $30 \mathrm{mg}$ capsule & 98.93 & 0.50 & 1.07 \\
& $45 \mathrm{mg}$ capsule & 99.75 & 0.79 & 0.25 \\
& $75 \mathrm{mg}$ capsule & 96.03 & 0.90 & 3.97 \\
\cline { 2 - 5 } & Day 1 & 96.03 & 0.90 & 3.97 \\
Intermediate precision $^{a, b}$ & Day 2 & 96.14 & 0.88 & 3.86 \\
& Day 3 & 96.32 & 0.91 & 3.68 \\
& $X$ & 96.16 & 0.15 & 3.84 \\
\hline \hline
\end{tabular}

${ }^{a} n=6$

${ }^{b}$ Only $75 \mathrm{mg}$ capsules were tested in Intermediate precision 
Table 5

Accuracy of the method

\begin{tabular}{ccccc}
\hline \hline $\begin{array}{c}\text { Amount added } \\
\left(\mathrm{mg} \mathrm{ml}^{-1}\right)\end{array}$ & $\begin{array}{c}\text { Amount found } \\
\left(\mathrm{mg} \mathrm{ml}^{-1}\right)\end{array}$ & $\begin{array}{c}\text { Recovery } \\
(\%)\end{array}$ & $\begin{array}{c}\text { RSD } \\
(\%)\end{array}$ & $\begin{array}{c}\text { Bias } \\
(\%)\end{array}$ \\
\hline 0.1500 & 0.1500 & 100.00 & 0.59 & 0 \\
0.2259 & 0.2289 & 101.34 & 0.28 & 1.34 \\
0.3018 & 0.3010 & 99.74 & 0.16 & -0.26 \\
0.3776 & 0.3818 & 101.12 & 0.29 & 1.12 \\
0.4535 & 0.4496 & 99.13 & 0.15 & -0.87 \\
0.5294 & 0.5324 & 100.56 & 0.08 & 0.56 \\
\hline & $\bar{X}$ & 100.32 & 0.85 & 0.32 \\
\hline \hline
\end{tabular}

${ }^{{ }^{a} \text { Mean value of } 3 \text { determinations }}$

The average recovery for the tested amounts was $100.32 \% \pm 0.85 \%(n=6)$. Mean recovery (Table 5) for OP was between 99.13 and 101.34 $\%$ indicating that the developed method was accurate for the determination of OP in pharmaceutical formulation.

\subsubsection{Limit of detection and limit of quantification}

The limit of detection (LOD) and limit of quantification (LOQ) were $0.0162 \mu \mathrm{g} \mathrm{ml}^{-1}$ (corresponding to $0.324 \mathrm{ng}$ OP loaded onto column) and $0.0491 \mu \mathrm{g} \mathrm{ml}^{-1}$ (corresponding to $0.982 \mathrm{ng}$ OP loaded onto column), respectively. The proposed HPLC method for OP determination was demonstrated to be sensitive for performing the stability indicating assay and the assay evaluation for product release and stability studies and profiling of Tamiflu ${ }^{\circledR}$ capsules.

\subsubsection{Robustness}

Based on the obtained results from the method robustness $(\mathrm{RSD}<2 \%$ ), the proposed HPLC analytical method were demonstrated to be robust (Table 6).

Table 6

\section{Robustness of the method}

\begin{tabular}{lc}
\hline \hline Change in parameter & RSD $(\%)(n=3)$ \\
\hline Flow rate $\left(1.4 \mathrm{ml} \mathrm{min}^{-1}\right)$ & 1.01 \\
Flow rate $\left(1.6 \mathrm{ml} \mathrm{min}^{-1}\right)$ & 1.47 \\
Organic solvent concentration $(48 \%)$ & 0.49 \\
Organic solvent concentration $(52 \%)$ & 1.69 \\
Detection wavelength $(210 \mathrm{~nm})$ & 1.54 \\
Detection wavelength $(220 \mathrm{~nm})$ & 1.32 \\
Buffer $\mathrm{pH}(4.8)$ & 0.99 \\
Buffer $\mathrm{pH}(5.2)$ & 1.19 \\
Temperature $\left(22^{\circ} \mathrm{C}\right)$ & 0.94 \\
Temperature $\left(28^{\circ} \mathrm{C}\right)$ & 0.69 \\
\hline \hline
\end{tabular}




\subsection{Method applications}

The validated method was applied for the determination of OP in commercially available Tamiflu ${ }^{\circledR}$ capsules. Figure 2 illustrates two typical HPLC chromatograms obtained following the assay of OP reference standard solution and Tamiflu ${ }^{\circledR}$ capsules sample solution, respectively. The results of the assay $(n=6)$ undertaken yielded $98.93 \%(\mathrm{RSD}=0.50 \%)$, $99.75 \%(\mathrm{RSD}=0.79 \%)$, and $96.03 \%(\mathrm{RSD}=$ $0.90 \%$ ) of label claim for oseltamivir in Tamiflu $^{\circledR} 30 \mathrm{mg}$ capsule, $45 \mathrm{mg}$ capsule, and $75 \mathrm{mg}$ capsule, respectively (Table 4 ). The average retention time of oseltamivir was approximately $5.2 \mathrm{~min}$. The results of the assay indicate that the method is specific for the analysis of oseltamivir without interference from the excipients used to formulate and produce these capsules.

\section{CONCLUSIONS}

The proposed HPLC method allows a simple, accurate, precise and rapid determination of oseltamivir API in pharmaceutical dosage forms. The important features and advantages of this method include: simple sample treatment with sonication of small amounts of powder sample at ambient temperature, shorter elution time (less than $6 \mathrm{~min}$ ) and shorter analysis time than in the previously reported methods (less than $10 \mathrm{~min}$ ); good precision (RSD less than $2 \%$ ) and high recovery (greater than 99\%). Furthermore, avoiding long steps of sample preparation and using methanol instead of acetonitrile in a mobile phase considerably reduces the laboratory expenses, while still providing adequate sensitivity for determination of OP in commercially available Tamiflu ${ }^{\circledR}$ capsules. The proposed method could be applicable for routine analysis in pharmaceutical analytical laboratory, in chemical stability studies as well as for the evaluation of potentially counterfeit Tamiflu ${ }^{\circledR}$ products.

\section{REFERENCES}

[1] Writing Committee of the WHO Consultation on Clinical Aspects of Pandemic (H1N1) 2009 Influenza. Clinical Aspects of Pandemic 2009 Influenza A (H1N1) Virus Infection, N. Engl. J. Med., 362, 1708-1719 (2010).

[2] Novel Swine-Origin Influenza A (H1N1) Virus Investigation Team. Emergence of a novel swine origin influenza A (H1N1) virus in humans. $N$. Engl. J. Med., 360, 2605-2615 (2009).

[3] Y. Itoh, K. Shinya, M. Kiso, T. Watanabe, Y. Sakoda, M. Hatta, Y. Muramoto, D. Tamura, Y. Sakai-Tagawa, T Noda, S. Sakabe, M. Imai, Y. Hatta, S. Watanabe, C. Li, S. Yamada, K. Fujii, S. Murakami, H. Imai, S. Kakugawa, M. Ito, R. Takano, K. Iwatsuki-Horimoto, M. Shimojima, T. Horimoto, H. Goto, K. Takahashi, A. Makino, H. Ishigaki, M. Nakayama, M. Okamatsu, K. Takahashi, D. Warshauer, P. A. Shult, R. Saito, H. Suzuki, Y. Furuta, M. Yamashita, K. Mitamura, K. Nakano, M. Nakamura, R. Brockman-Schneider, H. Mitamura, M. Yamazaki, N. Sugaya, M. Suresh, M. Ozawa, G. Neumann, J. Gern, H. Kida, $\mathrm{K}$. Ogasawara, Y. Kawaoka, In vitro and in vivo characterization of new swine origin H1N1 influenza viruses, Nature, 460, 1021-1025 (2009).

[4] M. L. Lim, C. Y. Chong, W. S. Tee, W. Y. Lim, J. J. Chee, Influenza A/H1N1 (2009) infection in pregnancy - an Asian perspective. BJOG, 117, 551-556 (2010).

[5] WHO guidelines for pharmacological management of pandemic (H1N1) 2009 influenza and other influenza viruses. Geneva: World Health Organization, February 2010.http://www.who. $\mathrm{int} / \mathrm{csr} / \mathrm{resources} /$ publications/swineflu/h1n1 use_antivirals_20090820/en/index.html, (last accessed March 7, 2012).

[6] Tamiflu SmPC. Tamiflu Summary of Product Characteristics. http://emc.medicines.org.uk (7 March 2012, date last accessed).

[7] B. E. Davies, Pharmacokinetics of oseltamivir: an oral antiviral for the treatment and prophylaxis of influenza in diverse populations, J. Antimicrob. Chemother, 65, 5-10 (2010).

[8] M. E. Bosch, C. Bosch Ojeda, A. J. Ruiz Sánchez, F. Sánchez Rojas, Analytical methodologies for the determination of oseltamivir, Res. J. Pharm. Biol. Chem. Sci., 1, 368-376 (2010).

[9] M. L. Avramov Ivic, S. D. Petrovic, D. Z. Mijin, K. M. Drljevic-Duric, The qualitative determi- 
nation of oseltamivir phosphate in tamiflu ${ }^{\circledR}$ capsule by cyclic voltammetry, Hem. Ind., 65, 87-91 (2011).

[10] A. Y. C. Tong, R. Braund, E. W. Tan, L. A. Tremblay, T. Stringer, K. Trought, B. M. Peake, UV-induced photodegradation of oseltamivir (Tamiflu) in water, Environ. Chem., 8, 182-189 (2011).

[11] M. J. Navas, A. M. Jimenez. Analytical methods to determine anti-influenza drugs, Crit. Rev. Anal. Chem., 41, 81-97 (2011).।

[12] H. Wiltshire, B. Wiltshire, A. Citron, A. T. Clarke, C. Serpe, D. Gray, W. Herron, Development of a high-performance liquid chromatographic mass spectrometric assay for the specific and sensitive quantification of Ro 64-0802, an anti-influenza drug, and its pro-drug, oseltamivir, in human and animal plasma and urine. J. Chromatogr. B Biomed. Sci. Appl., 745, 373-388 (2000).

[13] W. Kromdijk, H. Rosing, M. P. van den Broek, J. H. Beijnen, A. D. Huitema, Quantitative determination of oseltamivir and oseltamivir carboxylate in human fluoride EDTA plasma including the ex vivo stability using high-performance liquid chromatography coupled with electrospray ionization tandem mass spectrometry. J. Chromatogr. B Analyt. Technol. Biomed. Life Sci., 891-892, 57-63 (2012).

[14] N. Lindegardh, T. T. Hien, J. Farrar, P. Singhasivanon, N. J. White, N. P. Day, A simple and rapid liquid chromatographic assay for the evaluation of potentially counterfeit Tamiflu ${ }^{\circledR}, J$. Pharm. Biomed. Anal., 42, 430-433 (2006)

[15] J. Joseph-Charles, C. Geneste, E. Laborde-Kummer, R. Gheyouche, H. Boudis, J. P. Dubost, Development and validation of a rapid HPLC method for the determination of oseltamivir phosphate in Tamiflu and generic versions. J. Pharm. Biomed. Anal., 44, 1008-1013 (2007).

[16] C. Fuke, Y. Ihama, T. Miyazaki, Analysis of oseltamivir active metabolite, oseltamivir carboxylate, in biological materials by HPLC-UV in a case of death following ingestion of Tamiflu, Leg. Med., 10, 83-87 (2008).

[17] G. Bahrami, B. Mohammadi, A. Kiani, Determination of oseltamivir carboxylic acid in human se- rum by solid phase extraction and high performance liquid chromatography with UV detection, $J$. Chrom. B: Anal. Technol. Biomed. Life Sci., 864, 38-42 (2008).

[18] B. Narasimhan, K. Abida, K. Srinivas. Stability indicating RP-HPLC method development and validation for oseltamivir API, Chem. Pharm. Bull. (Tokyo), 56, 413-417 (2008).

[19] Z. Aydogmus, S. Caglar, S. Toker, RP-HPLC method for determination of oseltamivir phosphate in capsules and spiked plasma, Anal. Lett., 43, 2200-2209 (2010).

[20] H. Chabai, R. Ouarezki, S. Guermouche, M. H. Guermouche, Rapid determination of oseltamivir phosphate in pharmaceutical preparation using monolithic silica HPLC column. J. Liq. Chromatogr, Relat. Technol., 34 (17), 1913-1924 (2011).

[21] ICH Q2R1: Validation of Analytical Procedures: Text and Methodology. Proceeding of the International Conference on Harmonization of Technical Requirements for the Registration of Drugs for Human Use, Geneva, Switzerland, 1996.

[22] ICH, Guideline on Analytical Method Validation, Proceeding of International Convention on Quality for the Pharmaceutical Industry, Toronto, Canada, 2002.

[23] General Chapter $<1225>$, Validation of compendial methods, United States Pharmacopeia 32, National Formulary 27, Rockville, Md., USA, The United States Pharmacopeial Convention, Inc., (2009).

[24] General Chapter $<621>$, Chromatography, United States Pharmacopeia 32, National Formulary 27, Rockville, Md., USA, The United States Pharmacopeial Convention, Inc., (2009).

[25] Center for Drug Evaluation and Research. Food and Drug Administration. Reviewer Guidance: Validation of Chromatographic Methods. Washington, DC: Department of Health and Human Services; 1994.

[26] ICH Q1A: Stability Testing of New Drug Substances and Products. (International Conference on Harmonization of Technical Requirements for the Registration of Drugs for Human Use, Geneva, Switzerland, February 2003). 
